\title{
EPISTIMOLOGI AS-SUNNAH DALAM KAJIAN FILSAFAT HUKUM ISLAM
}

\author{
Muhazir \\ Dosen Fakultas Syariah IAIN Langsa \\ E-mail: muhazir@iainlangsa.ac.id
}

\begin{abstract}
The Sunnah experienced a very rapid development in the course of the study of the Sunnah, many studies of the Sunnah which discussed it with various approaches, say golzhiher analyzing the AsSunnah from the context of the sanad with a historical approach, studies of the Sunnah were studied by many people orentalis in various disciplines of science, they try to put forward new theories in order to examine and criticize the Sunnah of the Prophet which was caused by experiencing the purity of the text because there was interference after the Prophet died. Many criticisms occur and result in Muslim scholars who after completing and completing their education try to study with hermeneutical approaches.
\end{abstract}

Keywords: Sunnah, sanad, hermeneutical

\begin{abstract}
Abstrak. As-Sunnah mengalami perkembangan yang sangat pesat dalam perjalanan pengkajian tentang Sunnah, banyak kajian-kajian tentang Sunnah yang membahasnya dengan berbagai pendekatan, sebut saja golzhiher yang menganalisi As-Sunnah dari konteks sanad dengan pendekatan historis, kajian-kajian tentang Sunnah banyak dikaji oleh orang orentalis dalam berbagai kedisiplinan ilmu, mereka berusaha mengemukakan teori-teori baru dalam rangka menela'ah serta mengkritisi Sunnah nabi yang disebabkan telah mengalami kemurnian teks karena ada campur tangan setelah nabi wafat. Kritikan-kritikan banyak terjadi dan mengakibatkan cendikiawan muslim yang setelah melakukan dan menyelesaikan pendidikannya dibara berusaha mengakaji dengan pendekatan-pendekatan hermeneutika.
\end{abstract}

Kata kunci: As-Sunnah, sanad, hermeneutika

\section{Pendahuluan}

As-Sunnah merupakan sumber hukum kedua setelah al-Qur'an dalam Islam, hampir semua jumhur ulama terutama dari kalangan Sunni dan Syi'ah mengakui As-Sunnah sebagai sumber hukum. Bagi kaum Muslim di Indonesia yang mayoritas beraliran sunni, As-Sunnah menjadi sumber penting yang dijadikan sebagai sandaran utama, bahkan upayaupaya mengabaikan As-Sunnah di kalangan Muslim Indonesia dianggap sebagai upaya menghancurkan salah satu sendi agama Islam itu sendiri.

Terlepas dari permasalahan tersebut, bagi ummat Islam menyakini bahwa sunnah merupakan sumber hukum ke dua setelah quran, bahkan sunnah memiliki fungsi sebagai bayân li al-qurân. Sunnah merupakan cakupan yang merumuskan ketentuan hukum Islam secara realistis dan dipraktikan dalam kehidupan sehari-hari. Jika sekiranya as-Sunnah itu bukan merupakan hujjah dan tidak pula merupakan penjelasan atas al-Qur'an, sudah tentu kita tidak akan dapat melaksanakan, bagaimana cara kita beribadah dan melaksanakan ajaran-ajaran yang terdapat di dalam al-Qur'an. Lebih dari pada itu, apabila kajian sunnah baik dari segi doktinal maupun non-doktrinal dipahami dengan kajian filsafat hukum, maka akan kita temukan bahwa segala sesuatu yang telah digariskan oleh rasul memiliki hikmat yang sangat besar didalamnya.

\section{Terminologi As-Sunnah dan Al-Hadîst}

Terkadang kita sering terjebak dengan penggunaan istilah sunnah dan hadîst, pada dasarnya dua term tersebut sama dan secara umum sunnah terkadang dipahami hadîst dan sebaliknya. Namun, apabila ingin dikrucutkan antara sunnah dan hadîst maka dapat dikatakan bahwa sunnah bersifat universal dan hadîst bersifat lokal.

Kata sunnah dalam al-Quran disebutkan sebanyak enam belas kali, baik dalam bentuk mufrad maupun jama'. Al-Quran menggunakan istilah sunnah untuk beberapa konteks, yang secara garis besar berkenaan dengan dua hal. Pertama, ketetapan orang-orang terdahulu (sunnah al awwalîn), yang dimaksud dalam konteks ini adalah kejadian-kejadian yang menimpa mereka akibat dari perbuatan yang telah 
mereka lakukan. Kedua, ketetapan Allah (sunnatullah) yang dimaksud disini adalah cara atau aturan Allah yang berlaku bagi semua hambanya. ${ }^{1}$

Sunnah $^{2}$ digambarkan oleh Rasul berupa perjalanan baik dan perjalanan buruk sebagaimana yang terdapat dalam sunnah Rasul;

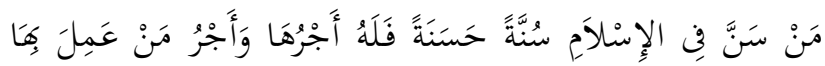

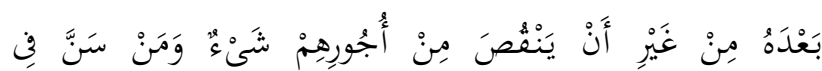

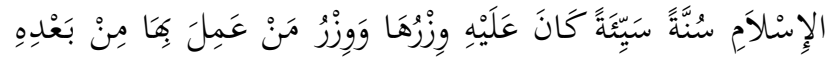

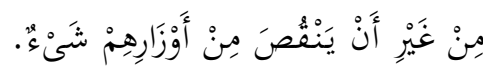

"Barang siapa yang mencontohkan jalan yang baik di dalam Islam, maka ia akan mendapat pahala dan pahala orang yang mengamalkannya setelahnya tanpa mengurangi pahala mereka sedikit pun. Dan barang siapa yang mencontohkan jalan yang jelek, maka ia akan mendapat dosa dan dosa orang yang mengerjakannya sesudahnya tanpa mengurangi dosa mereka sedikitpun". ${ }^{3}$

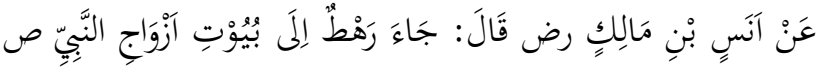

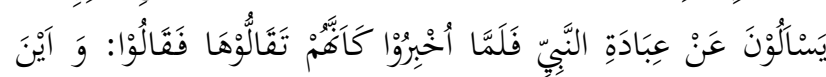

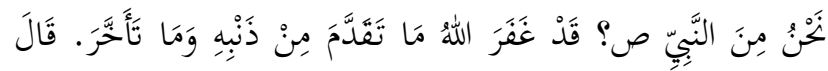

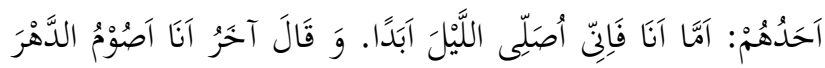

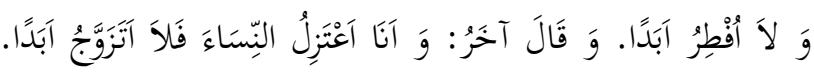

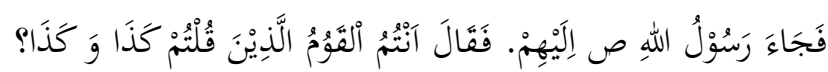

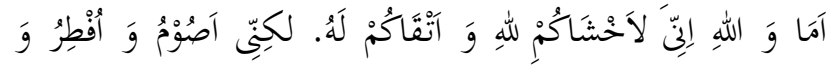

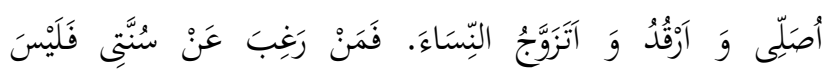

$$
\begin{aligned}
& \text { مِنّى.(البخارى ) }
\end{aligned}
$$

Dari Anas bin Malik RA, ia berkata: Ada sekelompok orang datang ke rumah istri-istri Nabi SAW, mereka menanyakan tentang ibadah Nabi

${ }^{1}$ Narulloh, Rekonstruksi Definisi Sunnah Sebagai Pijakan Kontekstualitas Pemahaman Hadîst, dalam Jurnal Ulul Albab Volume 15, No.1 Tahun 2014, 21

${ }^{2}$ Secara etimologis, sunnah memiliki beberapa arti; 'jalan yang ditempuh' (al-tharīqah al-maslūkah); 'kesinambungan' (aldawām); 'jalan yang baik' (al-tharīqah al-mahmüdah); dan 'jalan yang terus diulang-ulang yang baik atau yang buruk' (al-tharīqah al-mu'tādah hasanah wā sayyi'ah), ada juga yang mengungkapkan bahwa sunnah adalah 'adat kebiasaan' (al 'âdah) yakni jalan yang terus diulang-ulang oleh beragam manusia baik yang dianggap sebagai ibadah ataupun yang bukan ibad. Baca Ibrāhīm Anīs, et al. al-Mu 'jam al-Was i th, vol.1 (Kairo: t.p, 1972), hal. 456.

${ }_{3}^{3}$ Abu al-Husain ibn al-Hajjaj, Shahih Muslim, (Beirut: Dar alFiqr, tt) sunnah ke 2398.
SAW. Setelah mereka diberitahu, lalu mereka merasa bahwa amal mereka masih sedikit. Lalu mereka berkata, "Dimana kedudukan kita dari Nabi SAW, sedangkan Allah telah mengampuni beliau dari dosadosa beliau yang terdahulu dan yang kemudian". Seseorang diantara mereka berkata, "Adapun saya, sesungguhnya saya akan shalat malam terus". Yang lain berkata, "Saya akan puasa terus-menerus". Yang lain lagi berkata, "Adapun saya akan menjauhi wanita, saya tidak akan kawin selamanya". Kemudian Rasulullah SAW datang kepada mereka dan bersabda, "Apakah kalian yang tadi mengatakan demikian dan demikian. Ketahuilah, demi Allah, sesungguhnya aku adalah orang yang paling takut kepada Allah diantara kalian, dan orang yang paling bertaqwa kepada Allah diantara kalian. Sedangkan aku berpuasa dan berbuka, shalat dan tidur, dan aku mengawini wanita. Makabarangsiapa yang membenci sunnahku, bukanlah dari golonganku (HR. Bukhari)

Sebagian ulama hadîst menyamakan antara hadîst dan sunnah meskipun ada juga para ulama hadîst dan para cendikiawan muslim yang membedakan antara hadîst dan sunnah, ${ }^{4}$ sebagian

${ }^{4}$ Berbeda dengan pendapat di atas, Syahrûr menyatakan bahwa Hadîst adalah kehidupan Nabi Muhammad saw sebagai seorang nabi (pembawa berita) dan manusia yang hidup dalam dunia nyata bukan dialam imajinasi, Jadi Sunnah merupakan hasil interaksi beliau dengan kejadian-kejadian tertentu dalam situasi tertentu pula pada masa beliau hidup (produk sejarah). Dengan demikian, Sunnah bukanlah wahyu dari Allah swt, sebab Nabi saw dan para sahabat tidak menganggap Sunnah sebagai wahyu. Hal ini terbukti bahwa baik nabi maupun para sahabat tidak pernah memerintahkan untuk mengumpulkan dan menulis Hadîst.

Adapun sunnah menurut Syahrûr berarti mudah. Sebab, kata sunnah berasal Dari kata "sanna" yang berarti mudah, sebagaimana dikatakan" ma'un mas'nun" yang berarti air yang mengalir dengan mudah dan lancar. Menurutnya, pengertian ini sesuai dengan prinsip dasar ajaran Islam yaitu membawa kemudahan bagi umatnya. Syahrur menegaskan lagi bahwa sunnah yaitu metodologi penerapan hukum atau Al-Kitab yang mencakup persoalan hudud serta perbuatan batasan-batas local yang bersifat non-hudu dengan mempertimbangkan realitas nyata, waktu, tempat serta kondisi dimana hukum tersebut akan diterapkan. Dalam konteks lain Syahrur mendifinisikan bahwa sunnah adalah ijtihad nabi dalam menerapkan hukum-hukum alkitab yang berupa hudud, ibadah dan akhlak dengan bergerak diantara batasan-batasan dan menciptakan batasan temporal bagi persoalan yang belum ada pada saat itu. Selanjutnya Syahrûr mengklasifikasikan sunnah kepada sunnah Al-Nubuwwah dan Sunnah al-Risâlah. Adapun sunnah nubuwwah yaitu sunnah yang menyangkut keilmuan nabi tentang ilmu-ilmu alam seperti falaq dan keilmuan tentang manusia serta tentang alam ghaib seperti penjelasan tentang kehidupan diakhirat dan lain sebagainya sedangkan sunnah risalah yang berkaitan dengan hukum-hukum 
ulama berpendapat bahwa sunnah cakupannya lebih luas dari pada hadîst yang mencakup tradisi dan kebiasaan Rasul sedangkan hadîst tidak ada unsur tradisi (budaya). ada juga yang berpendapat bahwa sunnah berawal dari Rasul lahir sampai wafat dan ada juga yang berpendapat bahwa sunnah berlangsung dari masa awal kenabian. hal ini dapat kita telesuri dari pemaknaan sunnah dan hadîst.

Menurut jumhur ulama hadîst bahwa tidak ada perbedaan makna antara Hadîst dan sunnah, sebab kedua-duanya berasal dari Nabi Muhammad. Oleh karena itu, mereka mendefinisikan hadîst atau sunnah sebagai berikut:

Terminologi hadîst ${ }^{5}$ menurut ulama ushûl dan hadîst;

$$
\text { اَقَوَالُ النبي صلى الله عليه وسلم وافعالهُ وَاَحْوَا لُهُ6 }
$$

"Segala perkataan Nabi, perbuatan, dan hal ihwalnya."

Terminologi sunnah menurut ulama ushûl dan hadîst:

$$
\begin{aligned}
& \text { ما اثِرَ عنِ النبى ص م مِن قولٍ أو فعل أو تقرير أو صفة أو خَلْقِيّةٍ }
\end{aligned}
$$

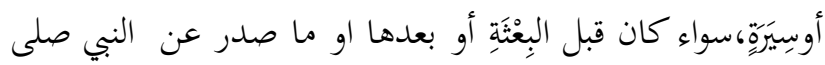

$$
\begin{aligned}
& \text { الله عليه وسلم غير القرآن من قولِ أو فعل أو تقرير } 7
\end{aligned}
$$

"Segala sesuatu yang bersumber dari Nabi saw dalam bentuk ucapan, perbuatan, penetapan, perangai atau sopan santun ataupun sepak terjang perjuangannya, baik sebelum maupun sesudah diangkat menjadi Rasul atau sesuatu yang disandarkan kepada Nabi SAW Selain al-Qurân baik berupa bentuk ucapan, perbuatan.

islam seperti puasa, shalat, haji, dan lainnya. Baca Sahiron Syamsuddin. (Pengantar): Hermeneutika al-Quran dan Sunnah (Yogyakarta, Elsaq Press, 2010), hal.397.

5 "Sunnah" atau al-Hadîst menurut bahasa, berarti al-jadid (sesuatu yang baru), lawan kata dari al-qadim. Kata sunnah juga berarti al-khabar (berita) yaitu sesuatu yang dipercakapkan dan dipindahkan dari seseorang kepada orang lain. Bentuk pluralnya adalah al-Hadîst. Sunnah sebagaimana tinjauan Abdul Baqa' adalah isim dari tahdits yang berarti pembicaraan. Kemudian didefinisikan sebagai ucapan, perbuatan atau penetapan yang disandarkan kepada Nabi SAW. Barangkali para ulama telah memahami arti ini ketika berpendapat bahwa mufrad kata Hadîst adalah uhdutsah (buah pembicaraan). Lalu kata aHadîst itu dijadikan jama' dari kata Hadîst. lihat Zainul Arifin, Studi Kitab Sunnah, (Surabaya: al-Muna, 2010), hal.1.

6 'Abdul Wahhab khallaf, 'Ilmu Ushul Fiqh, (Beirut: Dar AlQutub, 2010), hal. 27.

7 Abdul Karim Zaidan, Al wajiz fi Ushul Fiqh, (Beirut: Muasasah Risalah, tt), hal. 161.
Kebanyakan teori klasik mengenai sunnah memasukkan tiga elemen yang penting. Dalam buku pegangan hukum Islam klasik, istilah sunnah menunjuk kepada contoh autoritatif yang diberikan oleh Nabi Muhammad saw. dan yang dicatat dalam tradisi (hadîts, akhbâr) mengenai perkataannya, tindakannya, persetujuannya atas perkataan atau perbuatan orang lain, serta karakteristik (shîfah) kepribadiannya. Dengan demikian, elemen pembatas pertama dalam doktrin sunnah, dalam bentuknya yang matang, merupakan identifikasi eksklusif istilah tersebut dengan Nabi Muhammad; sunnah dalam pengertian adalah sunnah Nabi. Elemen kedua teori klasik sunnah adalah identifikasi sempurna dengan riwayat-riwayat sunnah yang bisa dilacak dengan mata rantainya hingga Nabi Muhammad dan dinilai sahih; sunnah sepadan dengan tradisi autentik. Sifat pembatas sunnah yang ketiga dan terakhir adalah statusnya sebagai wahyu. Sunnah, menurut ajaran klasik, diwahyukan oleh Allah melalui perantara Rasulullah seperti halnya al-Qurân. ${ }^{8}$

Al-Khaththîb mengemukakan bahwa pengertian sunnah menurut muhadditsun lebih dikhususkan pada semua yang diriwayatkan dari Rasulullah setelah menjadi Rasul (nubuwwah), baik perkataan, perbuatan, dan ketetapannya. Berbeda lagi pendapat ushuliyyun yang mengatakan bahwa pengertian sunnah hanyalah terbatas kepada sunnah qawliyah (perkataan) Nabi saja, karena sunnah lebih umum pengertiannya dari pada pengertian sunnah. ${ }^{9}$

Al-Khaththîb membedakan pengertian sunnah berdasarkan pandangan para ahli sunnah, ushûl, dan fiqh. Pertama, ahli sunnah yang berpendapat bahwa sunnah adalah segala sesuatu yang disandarkan kepada Rasulullah, baik perkataan, perbuatan, taqrîr, perilaku, maupun seluk beluk kehidupannya, baik sebelum diangkat menjadi Rasul (seperti tahannust di gua Hira') ataupun sesudahnya. Pengertian sunnah di sini sama dengan pengertian hadist. Kedua, ahli ushûl fiqh mendefinisikan sunnah dengan segala sesuatu yang berasal dari Nabi Muhammad selain alQuran, baik berupa perkataan, perbuatan, dan taqrîr

8 Emawati, Sunnah Dan Sunnah Sebagai Landasan Tradisi Dalam Islam: Analisis Historis Terminologis, dalam Jurnal Ulumuna, Volume XV Nomor 2 Desember 2011, hal. 379.

${ }^{9}$ Muhammad 'Ajjaj al-Khaththib, Ushul al-Hadîst 'Ulumuh wa Mushthalahuh (Beirut: Dar al-Fikr, 1989), hal. 27. 
yang dapat dijadikan dalil hukum syara'. Dan ketiga, sunnah dalam istilah ahli figh diartikan segala sesuatu yang ditetapkan dari Nabi Muhammad dan bukan termasuk dalam fardhu ataupun wajib. ${ }^{10}$

Menurut Syuhudi Ismail, ${ }^{11}$ bila ditinjau dari segi kualitas amaliyah dan periwayatannya, maka hadîst berada di bawah sunnah, sebab hadîst merupakan suatu berita tentang sebuah peristiwa yang disandarkan pada Nabi, meski hanya sekali saja Nabi melakukannya dan hanya satu orang saja yang meriwayatkannya. Adapun sunnah merupakan amaliyah yang terus menerus dilaksanakan Nabi beserta sahabatnya, setelah itu dilakukan dan dilestarikan secara terus menerus oleh generasi berikutnya. Sebagai konsekwensinya, sunnah mempunyai satu tingkat lebih tinggi dari pada hadîst dari segi kekuatan hukumnya. Tetapi, meskipun berbeda, keduanya sama-sama bersumber dari Nabi, dengan dasar inilah mayoritas ahli Hadîst menganggap tidak ada. ${ }^{12}$

Pemahaman Suhudi terhadap sunnah sama halnya pemahaman tradisionalis yang mengacu pada kitabkitab klasik. Hal ini dibuktikan dengan karangan bukunya yang berjudul "pengantar ilmu sunnah" dalam buku itu Syuhudi banyak menulis tetang ilmu sunnah dan makna sunnah menurutnya sama dengan pemahaman ulama-ulama terdahulu, hanya saja dalam perkembangan keilmuan syuhudi lebih teliti dalam memahami teks sunnah secara historis atau diikuti kajian sejarah terbentuknya sunnah tersebut. Dalam buku "pengantar ilmu sunnah" Syuhudi juga mengklasifikasikan kandungan isi sunnah secara umum terbagi menjadi 4 aspek., pertama, berisi sejara, kedua, berisi akhlaq, ketiga, tentang aqidah, keempat berisi tentang hukum. ${ }^{13}$

Kajian tentang sunnah selalu berkaitan tentang nabi karena secara umu dikalangan para ulama

\footnotetext{
${ }^{10}$ Muhammad 'Ajjaj al-Khaththib, Ushul al-Hadîst,.19

11 Prof. M. Syuhudi merupakan salah satu mahasiswa yang belajar dan meneliti sunnah dari perguruan tinggi islam di Indonesia. Ia mulai dikenal khalayak umum, khususnya pecinta ilmu sunnah setelah desertasinya yang berjudul "Kaedah keshahihan sanad Sunnah, telaah kritis dan tinjauan dengan pendekatan ilmu sejarah" seorang mahasiswa yang langsung diasuh oleh Prof. Dr. Quraisy syihab ini dikenal dengan keuletannya dalam meneliti dan menela'ah sunnah secara continuous dibidang sunnah.

${ }^{12}$ Narulloh, Rekonstruksi Definisi Sunnah,.21

${ }^{13}$ M.Syuhudi Ismail. M.Syuhudi Ismail. Pengantar Ilmu Sunnah. (Bandung: Angkasa, 1991), hal. 49.
}

sunnah memahami sunnah sebagai segala sesuatu yang disandarkan kepada nabi dalam makna lebih luas yang bersumber dari nabi ${ }^{14}$, menurut syahrur tentang kenabian, bahwa nabi bertugas mengubah yang mutlak menjadi yang nisbi yang bergerak dalam bingkaian pengawasan allah atau pada masa kenabiannya di semenanjung arab dan inilah kebenaran dan hakikat sunnah Nabi dalam posisi ini nabi merupakan seorang mujtahid yang mengkonstruk dari yang bersifat teks menjadi aplikatif. Konsep ini serupa dengan konsep yang ditawarkan oleh Hegel dengan teori absolutnya tentang Islam, menurut hegel susunan rasional atas sifat yang absolute dalam artian nabi merupakan interpretative hukum-hukum ilahiyah yang dituangkan kedalam realitas nisbi. ${ }^{15}$

Terkait tentang ralasi antara amaliayah nabi dalam non-ibadah, non-ghaib dan hukum apakah merupakan wahyu atau ijtihad, dalam hal ini Syahrur berpendapat bahwa jika dikaitkan dalam konteks tersebut maka ijtihad nabi bukan wahyu, lebih lanjut syahrur menjelaskan tentang ayat al-Quran dalam Surat An-Najm ayat 3-4:

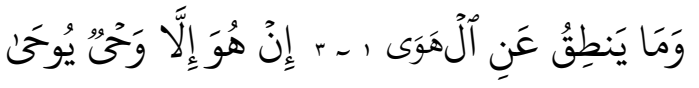

"dan tiadalah yang diucapkannya itu (Al Qur'an) menurut kemauan hawa nafsunya. Ucapannya itu tiada lain hanyalah wahyu yang diwahyukan (kepadanya).

Ayat ini dipakai dalil yang digunakan untuk melegitimasi bahwa apa yang dikatakan oleh nabi adalah wahyu. Dari ayat tersebut menurut syahrur bukanlah perkataan nabi melainkan merujuk kepada al-quran lebih lanjut syahrur menjelaskan bahwa dhamîr ya pada lafalz "yantiqu” merujuk kepada alquran bukan nabi. Selanjutnya menurut syahrur bahwa yant tersebut turun dimakkah di mana orang arab meragukan akan kebenaran al-quran sebagai tatanan baru, bukan meragukan akan kebenaran perkataan nabi, jadi menurutnya ayat tersebut tidak berkaitan dengan nabi melainkan berkaitan dengan kebenaran al-quran sebagai wahyu, berangkat dari konsep Islam absolute dan islam nisbi bahwa dalam

\footnotetext{
${ }^{14}$ Daniel Juned. Ilmu Sunnah. (Jakarta: Erlangga,2010), hal. 78.

${ }^{15}$ Sahiron Syamsuddin. (Pengantar): Hermeneutika al-Qur'an
} dan Sunnah. 395 
aspek pemahaman nisbi diluar persoalan hudud dan perkara yang berhubungan dengan non ibadah bukanlah wahyu. Secara tegas syahrur menegaskan bahwa sunnah dan sunnah bukanlah wahyu, lebih jelas lagi syahrur mengatakan bahwa sunnah rasul tidak bersifat mutlaq yang bersifat mutlaq yaitu firman allah (al-quran), lanjutnya yang harus ditaati pada nabi yaitu yang bersifat hukum-hukum, ibadah serta akhlaq, karena menurut syahrur kehidupan nabi dipengaruhi oleh politik, budaya, ekonomi serta sosio-cultural pada masa itu (abad $7 \mathrm{H})$.

Pernyataan yang dianggap liberalis bagi kelompok yang kontra bahwa Menurut syahrur kehidupan nabi merupakan sebuah bentuk percontohan bagi umat Islam yang melandasi hidup sesuai dengan apa yang diperintahkan oleh allah, kehidupan nabi merupakan model kehidupan muslim yang pertama, begitu juga selanjutnya bahwa kita memang harus menghargai, menghormati mengagungkan Nabi Muhammad dan para sahabat nabi bukan berarti kita harus mengangung-agungkan penafsiran mereka terhadap sumber-sumber hukum Islam, jadi wajar saja bagi golongan yang menentang gagasan syahrur ini dengan mengatakan bahwa syahrur adalah "an enemy of Islam" atau "a western zionist agent".

Kembali lagi tentang permasalahan macammacam sunnah, menurut syahrur Sunnah Nubuwwah dibagi lagi menjadi dua macam yaitu. Pertama, sunnah yang berhubungan dengan hal-hal ghaib dan pemahaman umum tentang al-quran bukan berarti mentakwilkan al-quran karena posisi nabi bukan sebagai pentakwil. Kedua yang berhubungan dengan uraian bersifat informative belaka dan tidak harus dita'ati. Diantara sunnah nubuwwah tersebut ada yang bersifat relevan dengan konstruk zaman sekarang, dan dalam kondisi seperti ini dapat kita ambil dan dapat juga tidak diambil.

Perubahan dan pergeseran makna sunnah pasca kemunculan Islam, menurut Goldziher disebabkan umat islam sangat menghormati dan mentaati model perilaku Nabi, sebagaimana orang Arab (penyembah berhala) mentaati tradisi nenek moyang mereka. Dengan demikian, konsep islam tentang sunnah merupakan revisi pernyataan-pernyataan dari pandangan-pandangan masyarakat Arab kuno. Gagasan Goldziher tersebut ditentang oleh Azami.
Menurut Azami, umat muslim mentaati dan meneladani perilaku Nabi, dikarenakan mengikuti perintah Allah dan juga rasulnya, dan bukan seperti halnya orang Arab yang menyembah berhala mentaati tradisi nenek moyangnya. Maka dari itu ada pemisah antara sunnah masyarakat jahiliyyah dengan sunnah masyarakat Islam, yaitu perintah Allah dan perintah Rasulnya.

\section{As-Sunnah dalam Kajian Filsafat Hukum Islam}

Kesakralan sunnah mengakibatkan kaum muslim tradisionalis dan fundamentalis memahami sunnah sebagai suatu ketentuan yang tidak dapat diganggu gugat keabsahannya. Hal ini berbeda dengan kaum orentalis seperti Josep Schact ${ }^{16}$ dengan teori commun link yang seterusnya dikembangkan oleh Juynboll. ${ }^{17}$ Demikian juga kritikan Goldzhiher ${ }^{18}$ lakukan terhadap sunnah Nabi yang harus dilakukan rekonstruksi matan melalui upaya kolaborasi antara matn dengan kondisi sosio-cultural baik dari aspek politik dan budaya pada saat sunnah itu di demonstrasikan oleh Rasul dan para sahabat.

Dalam perkembangannya, sunnah nabi telah mengalami perjalanan yang sangat dahsyat, melalui beberapa kajian di Barat yang berusaha mengusik keontetikan sunnah, tidak hanya itu saja. bahkan mereka menganggap telah terjadi pemalsuan sunnah setelah wafatnya nabi. Pada masa sekarang ini telah banyak kajian-kajian sunnah dari kaum orentalis yang menyudutkan sunnah serta menggoyahkan keakuratan sunnah dengan menelusuri sejarah kodifikasi sunnah.

\footnotetext{
${ }^{16}$ Joseph Schacht dianggap sebagai pelopor aliran Revisionist dalam Orientalisme, yang meragukan kemurnian sunnah sehingga menurutnya sunnah merupakan interpretative ulama fiqh seperti imam syafi'I dan imam mazhab lainnya, seihingga dia mengangap bahwa sunnah yang digunakan oleh ulama fiqh merupakan interpretativnya yang digunakan untuk menguatkan aspek norma hukum yang dilakukan oleh para ulama fiqh, sehingga dengan dalih itu Schacht menyatakan bahwa sunnah yang digunakan oleh ulama fiqh talah berhasil membentuk basisbasish norma hukum melalui sunnah yang telah disesuaikan.

17 Merupakan penerus dari tiori yang dicetuskan oleh josep Schacht meskipun pada aspek yang lain juynbool berbeda dengan josep Schacht.

${ }^{18}$ Menurut perkiraan M.M. Azami adalah sarjana Barat yang pertama kali melakukan kajian terntang Hadîst. Yang melambungkan namanya adalah karyanya yang berjudul Muhammedanische Studien (Studi Islam).
} 
Pada konteks yang dramatis ini, untuk mengembangkan kajian sunnah serta memformulasikan konsep sunnah, serta merespon dan menjawab pandangan ummat saat ini baik ulama koservatif maupun orentalis, kajian-kajian orentalis yang meragukan dikarenakan proses kodifikasi sunnah jauh setelah nabi wafat, sehingga dimungkinkan munculnya sunnah-sunnah yang tidak sesuan seperti apa yang di sabdakan nabi,

Sunnah memiliki pesan yang bersifat universal sehingga dibutuhkan pemahaman yang utuh. Jika terjadi kesalahan pemahaman baik secara historis yang berkaitan dengan konteks kejadianya, maka akan mengakibatkan hilangnya makna yang terkandung dalam al-Quran dan sunnah, penekanan yang dilakukan terhadap pemahaman yang utuh yaitu. Bagaiman para pembaca yang mentafsirkan atau yang menala'ah suatu teks tidak terkonstruk pemahamanya terhadap teks saja, melainkan melihat pesan-pesan yang disampaikan pada saat sunnah itu di sampaikan oleh rasul.

Sunnah yang diucapkan, dikerjakan atau yang ditetapkan oleh Rasul memiliki peran penting dalam kajian hukum, karena tidak semuanya yang ada dalam al-Quran dapat diapahami tanpa adanya petunjuk dari Rasul, karena rasul meruakan passenger memiliki peran penting dalam menjelaskan apa yang diinginkan oleh allah dan Rasul pula yang sudah memiliki legitimasi dari sang pencipta hukum sebeagai penjelas.

Para ulama sepakat kedudukan tertinggi adalah alQur'an atas semua orang muslim. Kedudukan Nabi berada pada posisi setelah al-Qur'an. Kedudukannya ini bukan bersumber dari penerimaan komunitas akan keberadaan Nabi sebagai seseorang yang mempunyai kekuasaan, tetapi posisinya diekspresikan melalui kehendak wahyu yang diturunkan Allah.

Kedudukan Sunnah Nabi sebagai sumber otoritatif ajaran Islam yang kedua, telah diterima oleh hampir seluruh ulama dan umat Islam, tidak saja dikalangan Sunni tapi juga di kalangan Syi'ah dan aliran Islam lainnya. Legitimasi otoritas ini tidak diraih dari pengakuan komunitas muslim terhadap Nabi sebagai orang yang berkuasa tapi diperoleh melaui kehendak Ilahiyah, dan selanjutnya status sunnah dapat diklasifikasikan menjadi dua macam yaitu ${ }^{19}$ :

1. Sebagai pengukuh (taukid) terhadap ayat-ayat AlQur'an. sunnah yang berfungsi sebagai pengukuh ayat-ayat Al-Qur'an jumlahnya banyak sekali, seperti sunnah-sunnah yang menunjukkan atas wajibnya shalat, zakat, haji, amal, berbuat baik, memberi maaf dan sebagainya, contohnya;

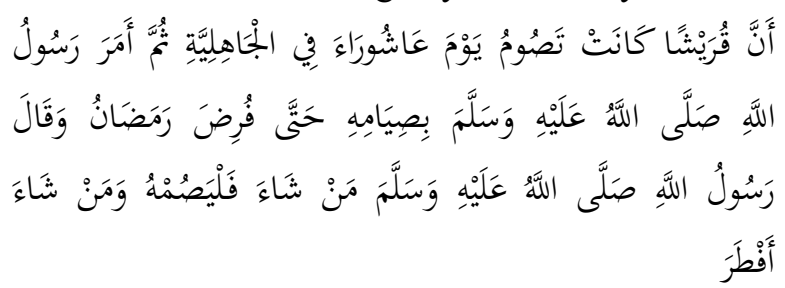

"Kaum Quraisy dahulu biasa melakukan puasa 'Asyura di masa jahiliyah. Kemudian Rasulullah shallallahu 'alaihi wa sallam pun memerintahkan untuk berpuasa pada hari itu sampai diwajibkannya puasa Ramadhan. Lantas Rasulullah shallallahu 'alaihi wa sallam bersabda, "Barang siapa yang ingin berpuasa pada hari itu 'Asyura maka silakan berpuasa. Dan barang siapa yang tidak ingin berpuasa silakan berbuka." (HR. Bukhari)

2. Sebagai penjelas terhadap maksud ayat-ayat AlQur'an.

Sunnah dalam fungsi ini diantaranya ialah sunnah yang menjelaskan segala sesuatu yang berhubungan dengan ibadah dan hukumhukumnya, dari segi praktiknya, syarat waktu dan tatacaranya, seperti masalah shalat dimana di dalam Al-Qur'an tidak disebutkan secara rinci tentang bilangan rakaat, waktu, syarat dan sebagainya. Tetapi semua itu dijelaskan oleh sunnah. sunnah juga dapat Membatasi lafadz yang masih muthlaq dari ayat-ayat Al-Qur'an, Mengkhususkan ayat-ayat Al-Qur'an yang bersifat umum.

Ada yang merumuskan kedudukan as-Sunnah terhadap al-Qur'an menjadi tiga hal, yaitu: a. Sunnah berfungsi menjelaskan ayat yang masih mubham, merinci ayat yang mujmal. b. Sunnah menambah kewajiban-kewajiban syara' yang ketentuan pokoknya telah ditetapkan dengan nash al-Qur'an. Seperti sunnah datang dengan membawa hukumhukum tambahan yang menyempurnakan ketentuan

19 'Abdul Wahhab khallaf, 'Ilmu Ushul Fiqh,..28-31 
pokok tersebut. c. Sunnah membawa hukum yang tidak ada ketentuan nashnya di dalam al-Qur'an. Seperti dalam masalah mu'amalat, yaitu al-Qur'an memerintahkan untuk memenuhi janji (perikatan). Hal ini perikatan mana yang sah dan yang halal serta perikatan yang haram dan yang tidak harus dipenuhi, disini as-Sunnah berperan untuk menjelaskannya. ${ }^{20}$

Dalam kajian filsafat hukum Islam, pendekatan yang digunakan yaitu pendekatan hikmah ${ }^{21}$ dan adapun sudut pandang yang digunakan dalam mengkaji filsafat hukum Islam yaitu ontology (hakikat), epistimologi (metode) dan aksiologi (tujuan), ketiga unsur ini berusaha menjawab aspek ilmiah dari kajian filsafat hukum Islam. sebagaimana yang kita ketahui bahwa Hukum Islam merupakan rangkaian aturan yang memiliki aspek positif apabila dikerjakan dan mendatangkan aspek negative apabila dilanggar.

Apabila pendekatan sumber hukum Islam dengan menggunakan pendekatan hikmah berarti dalam setiap hukum yang diperintahkan oleh rasul dalam sunnahnya baik itu berupa perintah maupun berupa himbauan maka akan mendatangkan hikmah yang cukup besar, hal ini dapat dibuktikan dengan beberapa contoh misalnya sunnah nabi tentang adab makan;

$$
\text { شاعاب رسول الله صلى الله عليه وسلم طعاما قط، كان اذا اشتهى }
$$

"Rasulullah sholallahu 'alaihi wasallam tidak pernah mencela makanan sama sekali. jika beliau mau maka beliau memakannya, dan jika tidak makan beliau meninggalkannya." (HR Bukhori, Muslim, Ahmad dan At-Tirmidzi).

$$
\text { فثلث لطعامه وثلث لشرابه وتلث لنفسه }
$$

"Sepertiga untuk makanan, sepertiga untuk minuman, dan sepertiga untuk nafas." (HR At-Tirmidzi, Ahmad dan Ibnu Majah)

Dari dua hadist tersebut diatas dapat memberikan kita gambaran bahwa secara logika tidak ada

\footnotetext{
${ }^{20}$ Suparman Usma, Filsafat Hukum Islam, (Jakarta: Laksita Indonesia, 2015), hal. 32.

21 Ibnu sina menjelasakan bahwa hikimah ialah mencari kesempurnaan diri manusia dengan dapat menggambarkan dan mebenarkan segarala hakikat baik yang bersifat teori maupun praktik menurut kadar kemampuan manusia. baca Dahlan Tamri, Filsafat Hukum Islam, (Malang: UIN Press, 2007), hal. 3.
}

hubungannga antara mencela dengan makanan karena makanan tidak bernyawa, tetapi rasul mengajarkan kita untuk tidak mencela makanan bahkan mengatakan perkataan yang baik terhadap makanan tersebut, dan ini secara ilmiah telah dibuktikan oleh Masaru Emoto ${ }^{22}$ salah satu peneliti melekul air dari jepang dari hasil temuannya menunjukan bahwa air dapat memberikan energi positif bagi tubuh apabila diajak komunikasi dan diucapkan kata-kata baik padanya. hal ini membuktikan kepada kita bahwa anjuran nabi tentang larangan mencela makanan memberikan efek bagi yang mengkonsumsinya.

Sama halnya dengan sunnah nabi yang kedua tentang Sepertiga untuk makanan, sepertiga untuk minuman, dan sepertiga untuk nafas, secara tidak sadar kita menganggap bahwa itu sekedar anjuran dan tidak wajib diikuti, padahal dari setiap perkartaan tersebut banyak mendatangkan hikmah bagi manusia, secara medis membuktikan apabila kondisi perut penuh maka akan mengakibatkan sesak bagian pernafasan dan hal ini berbahaya bagi tubuh manusia.

Kajian pendakatan filsafat hukum Islam membuktikan bahwa dari segala aturan baik itu yang bersifat perintah, larangan dan anjuran semua itu ada hikmah yang besar dan dapat membahayakan jiwa

\footnotetext{
22 Masaru Emoto lahir di Yokohama pada bulan Juli 1943. Dia adalah lulusan departemen Yokohama Municipal University dari humaniora dan ilmu pengetahuan dengan fokus pada Hubungan Internasional. Pada tahun 1986 ia mendirikan IHM Corporation di Tokyo. Ia menerima sertifikasi dari Open International University, Sri Lanka, sebagai seorang Dokter Pengobatan Alternatif pada Oktober 1992. Saat ini ia adalah kepala I.H.M. Umum Lembaga Penelitian dan Presiden Emeritus dari Water Internasional untuk Kehidupan Foundation, sebuah Organisasi non-profit. Dr. Masaru Emoto telah banyak meneliti tentng air, hasil dari penelitiannya ditulis antara lain dalam buku "The Hidden Massages in Water" (Pesan Tersembunyi dalam Air), "The Shape of Love" dan masih banyak buku yang berkaitan dengan penelitiannya. Beliau meneliti air dengan menggunkan suatu alat khusus. Penelitian ini benar benar menggunakan kaidah kaidah ilmiah. Sebagai seorang terapis ia menggunakan air cluster mikro dan MRA (Magnetic Resonance Analyzer) dalam sesi-nya. Dari MRA tersbebut ia menempatkan informasi tertentu ke dalam air dalam bentuk Hado (yang berarti "getaran" dalam bahasa Inggris). Tidak lama dari terapinya ia meyakinkannya bahwa air dapat menyimpan dan membawa informasi. Sudah cukup lama hipotesis ini telah dipercaya oleh orang-orang tertentu seperti homoeopaths atau mereka yang religius, meskipun belum terbukti secara ilmiah dan bahkan telah diabaikan atau ditertawakan oleh sebagian besar para ilmuwan. lihat https://en.wikipedia.org/wiki/Masaru_Emoto. diakses 25 Novemvber 2018.
} 
manusia baik secara langsung maupun secara tidak langsung. oleh karena itu penting kajian filsafat hukum islam dengan pendekatan hikmah dalam memahami sumber hukum Islam.

\section{Penutup}

Pemahaman tentang konsep sunnah sebagai sumber hukum kedua dalam isalm perlu dicermati lebih mendalam baik berkaitan dengan teks dan keonteks, penerikan kontekstualitas sunnah merupakan hal yang sangat penting untuk menghidupkan ajaran dalam sunnah Nabi, sehingga konsep as-sunnah dapat dipahami dan diterapkan dalam kehidupan sehari-hari, dari sudut pandang filsafat hukum islam yang cenderung memahami hukum dengan pendekatan hikmah cenderung memahami hukum kepada konsep kemaslahatan, maksudnya bahwa setiap hukum yang dibawa oleh nabi baik itu berupa sunnah maupun hadîst memiliki manfaat baik secara langsung maupun tidak langsung, bagi ummat islam menganggap sunnah sebagai pedoman yang sacral tidak dapat diganggu gugat sebaliknya ada yang menggap perlu memilah antara nilai normative dan nilai kultural dalam assunnah.

\section{DAFTAR PUSTAKA}

'Ajjaj al-Khaththib, Muhammad, Ushul al-Hadîst 'Ulumuh wa Mushthalahuh (Beirut: Dar al-Fikr, 1989)

al-Husain ibn al-Hajjaj, Abu, Shahih Muslim, (Beirut: Dar al-Fiqr, $\mathrm{tt}$ )

Arifin, Zainul, Studi Kitab Sunnah, (Surabaya: alMuna, 2010)

Emawati, Sunnah Dan Sunnah Sebagai Landasan Tradisi Dalam Islam: Analisis Historis Terminologis, dalam Jurnal Ulumuna, Volume XV Nomor 2

Ibrahim Anis ,et al. al-Mu'jam al-Wasith, vol.1 (Kairo: t.p, 1972).

Ismail, M. Syuhudi. M.Syuhudi Ismail. Pengantar Ilmu Sunnah. (Bandung: Angkasa, 1991)

Juned, Daniel. Ilmu Sunnah. (Jakarta: Erlangga,2010)

Karim Zaidan, Abdul, Al wajiz fi Ushul Fiqh, (Beirut: Muasasah Risalah, $\mathrm{tt}$ )

Narulloh, Rekonstruksi Definisi Sunnah Sebagai Pijakan Kontekstualitas Pemahaman Hadîst, dalam Jurnal Ulul Albab Volume 15, No.1 Tahun 2014.

Syamsuddin, Sahiron. (Pengantar): Hermeneutika alQur'an dan Sunnah (Yogyakarta, Elsaq Press, 2010)

Tamri, Dahlan, Filsafat Hukum Islam, (Malang: UIN Press, 2007)

Usma, Suparman, Filsafat Hukum Islam, (Jakarta: Laksita Indonesia, 2015)

Wahhab khallaf 'Abdul, 'Ilmu Ushul Fiqh, (Beirut: Dar Al-Qutub, 2010) 